\title{
Sea bottom characteristics affect depth limits of eelgrass Zostera marina
}

\author{
D. Krause-Jensen ${ }^{1, *}$, J. Carstensen ${ }^{2}$, S. L. Nielsen ${ }^{3}$, T. Dalsgaard ${ }^{1}$, \\ P. B. Christensen ${ }^{1}$, H. Fossing ${ }^{1}$, M. B. Rasmussen ${ }^{1}$ \\ ${ }^{1}$ National Environmental Research Institute, Department of Marine Ecology, Aarhus University, Vejlsøvej 25, \\ 8600 Silkeborg, Denmark \\ ${ }^{2}$ National Environmental Research Institute, Department of Marine Ecology, Aarhus University, Frederiksborgvej 399, \\ 4000 Roskilde, Denmark \\ ${ }^{3}$ Roskilde University, Department of Environmental, Social and Spatial Change (ENSPAC), Universitetsvej 1, \\ 4000 Roskilde, Denmark
}

\begin{abstract}
This study tested the hypothesis that sea bottom characteristics interact with light attenuation in the water column to regulate the depth limit of eelgrass Zostera marina L. A large-scale field data set on eelgrass depth limits, light climate and physico-chemical sea bottom characteristics was collected from Danish coastal waters and analyzed by statistical models. The results confirmed that light attenuation is the main predictor of eelgrass depth limits, but indicated that sediments characteristic of eutrophic conditions and physically protected environments also play a regulating role. Depth limits were moderately shallower when the sea bottom was rich in organic material, had high concentrations of nutrients and hydrogen sulfide, and had a physical structure characterized by fine particles, high porosity, high water content and low density. The effect of sediment variables was non-linear, and the sediment only affected depth limits beyond certain threshold levels characteristic of eutrophic conditions and physically protected environments. We argue that further reductions in nutrient loads can improve the state of eelgrass beds by ameliorating not only light conditions but also sediment quality and associated oxygen concentrations in the water column.
\end{abstract}

KEY WORDS: Eelgrass · Depth limit · Thresholds $\cdot$ Sediments $\cdot$ Light attenuation · Eutrophication

\section{INTRODUCTION}

Seagrasses are key components of coastal marine ecosystems. They produce and export considerable amounts of organic carbon, cycle nutrients, stabilize sediments and enhance biodiversity (e.g. Hemminga \& Duarte 2000). Seagrass ecosystems are, however, challenged by rapid environmental changes resulting from increased human pressure in coastal areas, and largescale losses of seagrass meadows have occurred worldwide (Short \& Wyllie-Echeverria 1996, Green \& Short 2003, Orth et al. 2006, Waycott et al. 2009). Among the major threats are increased nutrient discharges from land, which lead to reduced water clarity (Short \& Wyllie-Echeverria 1996), and ultimately alter sediment characteristics when organic material accumulates on the sea bottom in areas where hydrodynamics allow sedimentation.

Light limitation is the major factor controlling depth limits of seagrasses (Dennison 1987, Duarte 1991, Nielsen et al. 2002, Ralph et al. 2007). Seagrasses grow to more than $40 \mathrm{~m}$ depth in the clearest waters but are absent or penetrate to only a few meters depth in the most turbid areas (Duarte 1991). A recent largescale study confirmed this strong negative relationship between light attenuation and seagrass depth limits, but also demonstrated that the relationship is non-linear and differs between clear and turbid waters (Duarte et al. 2007). Seagrasses in turbid waters were thus found to have higher apparent light 
requirements than those growing in clearer waters (Duarte et al. 2007). Across Florida's Indian River Lagoon system, variation in light attenuation accounted for only half of the variation in depth limits (Steward et al. 2005). These observations demonstrate that factors other than light attenuation in the water column must play a regulating role for seagrass growth, as also pointed out by Koch (2001).

The depth limit represents a balance between carbon gain in terms of recruitment and growth fuelled by light, and carbon losses due to physiological processes such as respiration, exudation of dissolved organic carbon, reproduction and plant death, as well as direct physical removal of biomass by e.g. herbivory and physical exposure to currents and waves. The apparent higher light demand of seagrasses growing in shallow, turbid waters as compared to clear waters (Duarte et al. 2007) is likely due to increased carbon losses caused by other effects than reduced water clarity. Regression models which include water column nutrient concentration as well as water clarity as explanatory variables have been found to improve predictions of eelgrass depth limits (Greve \& Krause-Jensen 2005), thus supporting this idea. Increased nutrient concentrations stimulate the growth of epiphytes and opportunistic macroalgae which further shade seagrasses (Borum 1985, Drake et al. 2003, Kemp et al. 2004, Burkholder et al. 2007). Moreover, dead organic material may accumulate on the sea bottom, where hydrodynamic conditions allow this, thereby potentially affecting physical and chemical conditions for seagrasses (Hemminga 1998, Duarte et al. 2005).

As early as the late 19th century, Reinke (1889) noted that eelgrass in Kiel Bay grew down to $17 \mathrm{~m}$ depth on sandy bottoms but never grew deeper than $10 \mathrm{~m}$ on muddy bottoms. The idea that sea bottom conditions can affect depth colonization of seagrasses is therefore not new. Habitat characteristics such as concentrations of organic matter, presence of sulfide and grain size of surface sediments have been proposed as factors affecting the growth of submerged aquatic vegetation, which may help explain why seagrasses do not colonize all areas that fulfill their light demands (Koch 2001, Kemp et al. 2004). In this study we propose that these same factors also contribute to explaining variability in depth limits of eelgrass between areas.

Organic enrichment of the sea bottom creates soft and porous sediments that may not properly support anchoring of seagrass shoots, which may therefore be lost (Wicks et al. 2009). Dark, organic-rich sediments may further decrease bottom reflectance and thereby the light availability relative to a light, sandy bottom which reflects and scatters the light (Dierssen et al. 2003).
Deposition of organic matter on the sea bottom also changes the chemical environment of seagrasses towards higher concentrations of hydrogen sulfide and ammonium and more reduced conditions, causing significantly lower biomass and higher mortality of seagrass (Pérez et al. 2007). It is likely that high sulfide concentration in organically enriched sediments combined with low oxygen levels in the seagrass tissue provoke these negative effects on seagrasses, and that high oxygen demands of organic-rich sediments worsen the situation. Laboratory experiments have shown that sediment sulfides reduce the photosynthetic capacity of eelgrass (Goodman et al. 1995), and that combined exposure to hypoxia and hydrogen sulfide result in loss of above-ground biomass and increased mortality of eelgrass (Holmer \& Bondgaard 2001). Studies of oxygen and sulfide dynamics by microelectrodes in seagrass meristems also suggest that internal oxygen stress, caused by low water column oxygen content or poor plant performance (Greve et al. 2003), allows invasion of hydrogen sulfide over the roots and is a potential key factor in episodes of sudden die-off of seagrasses (Pedersen et al. 2004, Borum et al. 2005, Mascaró et al. 2009), such as those reported from the field following anoxic events (Plus et al. 2003). Eelgrass is especially sensitive to oxygen stress when temperatures are high (Pulido \& Borum 2010).

The range of seagrass-sediment interactions is further expanded and complicated by the fact that seagrasses affect the sediments surrounding them. Photosynthesis, respiration, and the growth and decay of seagrasses all influence the organic matter, nutrient and oxygen content of the sea bottom, and thereby its metabolism. As seagrasses produce large amounts of organic matter and enhance sedimentation of particles from the water column in their vicinity, they tend to form patches of organically enriched sediments and are, therefore, to some extent adapted to coping with such surroundings (Hemminga 1998, Duarte et al. 2005). Detrimental effects of poor sediment quality on seagrasses should therefore occur only above extreme levels of sediment variables.

This study aims to identify and quantify possible effects of chemical and physical sea bottom characteristics on the depth limits of eelgrass Zostera marina L. through a large-scale field study across Danish coastal areas which experienced marked eutrophication during the 20th century (Conley et al. 2007). We hypothesize that sediment variables interact with light attenuation in the water column to regulate seagrass depth limits, limiting colonization in deeper water at locations where the sea bottom is rich in organic matter, nutrients or hydrogen sulfide, and has a high water content that prevents the plants from anchoring properly. 


\section{MATERIALS AND METHODS}

Study site. The study included 42 sites where eelgrass depth limits in combination with chemical characteristics (content of organic matter, organic carbon, nutrients and hydrogen sulfide) and physical characteristics (grain size, water content, porosity, density) of the sea bottom in Danish coastal waters were quantified (Fig. 1). The sites were grouped in 6 main areas, each consisting of a number of basins (Fig. 1). Most sites (37) had complete records of these physico-chemical variables while the remaining 5 sites lacked a single variable. Information on Secchi depths characterizing the general light climate of each basin was available from water chemistry monitoring sites located centrally in the basins. Local departments of the Nature Agency take care of the monitoring and report the results to a national database maintained by the National Environmental Research Institute (NERI). The study sites were selected to represent a broad range of depth limits, light and sea bottom characteristics and included several locations where eelgrass depth limits were lower than expected based on light levels. Sites were also selected to be beyond the influence of mussel dredging activities. The tidal range in inner coastal waters and fjords is very small, ranging from $\sim 0.1$ to $0.5 \mathrm{~m}$.

Field sampling and laboratory analyses. Depth limits and sediment characteristics were assessed by the local departments of the Nature Agency and their con-

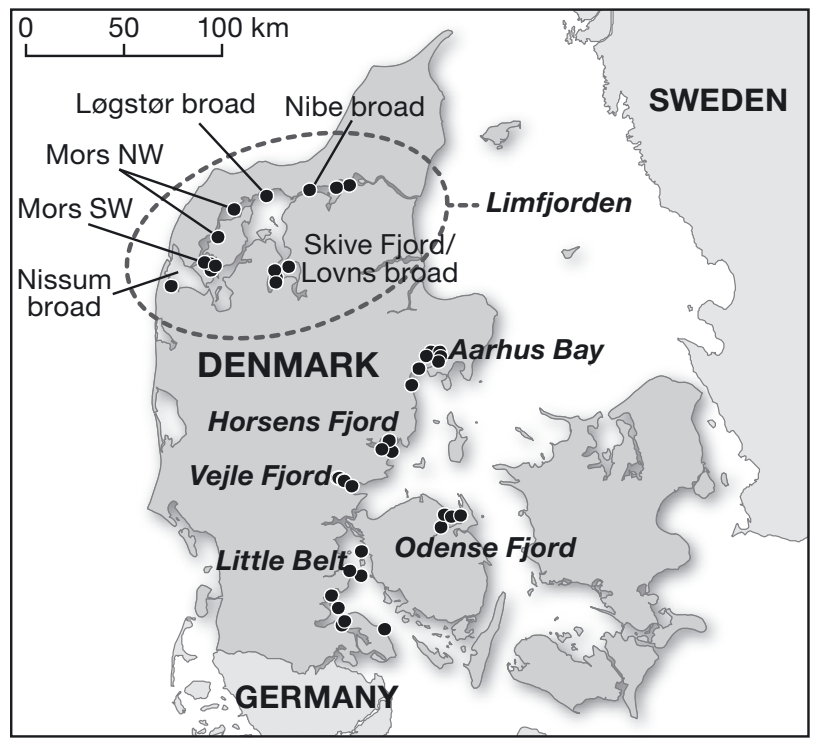

Fig. 1. Zostera marina. Sampling sites for eelgrass and sediment in Danish coastal waters. The sites (42 in total) were grouped in 6 main areas named on the map in bold italics. Within each area the sites were distributed in basins, each having a central monitoring station for Secchi depth. Not all sites are visible on the map as some are too close together to show sultants once during the summer (late July to mid September) 2005. Depth limits were measured by scuba divers as the deepest occurrence of eelgrass shoots.

At each site divers carefully collected sediment from the bare bottom between the scattered eelgrass shoots at the depth limit in a minimum of 5 plexiglas cores (length $300 \mathrm{~mm}$, inner diameter $52 \mathrm{~mm}$ ). In addition, temperature and oxygen concentration of bottom water were measured in situ in order to ensure similar conditions during laboratory incubations, and $25 \mathrm{l}$ bottom water was sampled at each site. The cores, firmly closed with rubber stoppers, were transported in cooler boxes to the laboratory where they were immediately incubated at in situ temperature and oxygen concentration in bottom water from the location.

On the following day, one core was used to measure hydrogen sulfide concentration of the pore water in $1 \mathrm{~cm}$ sections through the upper $10 \mathrm{~cm}$ sediment layer. Pore water was pressure filtered through a $0.45 \mu \mathrm{m}$ membrane filter (Millipore) under a gas-impermeable latex membrane. The first 5 drops of pore water were discarded. Subsequently, up to $2 \mathrm{ml}$ of pore water (determined by weight) was led through Tygon tubing directly into $1 \mathrm{ml}$ of $2 \% \mathrm{ZnCl}_{2}$ in a plastic vial in order to minimize exposure to the atmosphere. Hydrogen sulfide was then measured spectrophotometrically as described by Cline (1969).

The remaining sediment cores were sectioned and stored for later analysis: 3 of the cores were used to measure the content of organic matter, carbon and nitrogen, as well as water content and density from which sediment porosity was calculated. The analyses were conducted in $2 \mathrm{~cm}$ sections through the upper $10 \mathrm{~cm}$ sediment layer that represents the potential root zone of eelgrass. Sediment from the 3 cores was pooled. Dry weight was determined after drying to constant weight at $105^{\circ} \mathrm{C}$. Organic content was determined as weight loss on ignition at $550^{\circ} \mathrm{C}$. For determination of organic carbon and nitrogen content, the dried samples were homogenized and analyzed on an elemental analyzer (RoboPrep-C/N). Phosphorus was analyzed after acid destruction and subsequent colorimetric analysis of the ignited samples (Danish Standard DS 291 and Koroleff 1983). Water content (percent weight) was determined as the weight loss upon drying relative to the wet weight. Porosity $(\mathrm{ml}$ pore water $\mathrm{cm}^{-3}$ ), the fraction of void spaces in the sediment, was calculated as the volume of water lost upon drying each $2 \mathrm{~cm}$ section of the sediment core $\left(\sim 42 \mathrm{~cm}^{3}\right.$ sediment). Density (g wet weight $[\mathrm{ww}] \mathrm{cm}^{-3}$ ), i.e. mass per volume, was calculated from the wet weight of the sediment volume contained in each of the $2 \mathrm{~cm} \mathrm{sec-}$ tions of sediment.

A last core was used to measure grain size in $2 \mathrm{~cm}$ sections down to $10 \mathrm{~cm}$ depth. Grain size was assessed 
by wet sieving and homogenization through a $63 \mu \mathrm{m}$ sieve which separated the silt-clay fraction from the rest of the sample. After drying to constant weight, the silt-clay fraction was quantified as a percentage of the total dry weight. For all sediment variables we calculated average values for the top $10 \mathrm{~cm}\left(7 \mathrm{~cm}\right.$ for $\left.\mathrm{H}_{2} \mathrm{~S}\right)$, since deeper extraction of pore water was often not possible, and used these in the analyses of relationships between depth limits, light attenuation and sediment conditions.

Secchi depths are measured as part of the Danish National Monitoring Program with a sampling frequency of once or twice per month. In the data analyses we used average Secchi depths for the main growth season (March to September) over the years 1998 to 2005, thereby obtaining a relatively robust description of light attenuation.

Statistical modeling. The potential effect of the physical and chemical characteristics of the sediment as regulating factors of eelgrass depth limits in addition to light attenuation was investigated by a nonparametric approach, a Generalized Additive Model (GAM, Hastie and Tibshirani 1990), and a parametric approach, a non-linear regression of a threshold model. In both modeling approaches the depth limit of eelgrass ( $Z_{\text {eelgrass }}$ ) was assumed to be proportional (COefficients were denoted $a_{\mathrm{GAM}}$ and $a_{\mathrm{THRES}}$ ) to the Secchi depth $\left(Z_{\mathrm{SD}}\right)$ as a proxy for the primary regulating factor, light. Deviations from this relationship are referred to in the following as eelgrass anomaly. The first approach modeled deviations from the proportional relationship to Secchi depth by means of a smooth nonparametric function (LOESS smoother), $S(X)$ of the sediment variable $(X)$, where the smoothing parameter was selected by general cross validation in the GAM procedure:

$$
Z_{\text {eelgrass }}=a_{\mathrm{GAM}} \times Z_{\mathrm{SD}}+S(X)
$$

In the second approach, variations in eelgrass depth limit in addition to that explained by Secchi depth were modeled as a non-linear parametric response with no effect until crossing a specific threshold (Threshold) of the sediment variable $(X)$, using a hockey-stick type of model, i.e.

$$
Z_{\text {eelgrass }}=a_{\mathrm{THRES}} \times Z_{\mathrm{SD}}+\mathrm{k} \times X \times I(X>\text { Threshold })
$$

where the indicator function ( $I$ ) equals one if the argument is true, otherwise zero.

These 2 modeling approaches were applied separately to 9 different sediment variables (Table 1) as well as to linear combinations of the sediment variables in the form of the 3 first principal components of the sediment variables obtained from a Principal Component Analysis (PCA). A PCA involves a mathematical procedure that transforms a number of possibly correlated variables into a smaller number of uncorrelated variables called principal components. Sediment variables with a right-skewed distribution ( 7 out of the 9 variables) were log-transformed (Table 1) before further analysis to reduce the influence of observations in the upper tail distribution. As sediment variables were strongly autocorrelated it was not possible to isolate their individual effects through e.g. multiple regression analysis. The statistical analyses were carried out using PROC PRINCOMP, PROC GAM and PROC MODEL in SAS.

Calculation of eelgrass light demands. We calculated the percentage of surface irradiance available for eelgrass at the depth limit based on the relationship between the measured depth limit and Secchi depth obtained through the present study. We assumed that

Table 1. Zostera marina. Descriptive statistics and the first 3 principal components of a Principal Component Analysis (PCA) of 9 variables used to characterize the sediment at the depth limit of eelgrass. All values are given as averages from the upper $10 \mathrm{~cm}$ of the sediment, except $\mathrm{H}_{2} \mathrm{~S}$ where values represent the upper $7 \mathrm{~cm}$. The first principal component (PC1) accounts for as much of the variability in the sediment data as possible, and each succeeding component (PC2 and PC3) accounts for as much of the remaining variability as possible. Proportions of the total variation explained by each of PC1-3 are shown in the column heading; together, they explain $95.7 \%$ of the total variation. Values in the columns indicate the influence of each of the sediment

\begin{tabular}{|c|c|c|c|c|c|c|c|}
\hline & \multicolumn{4}{|c|}{ - Descriptive statistics - } & \multicolumn{3}{|c|}{ Principal components } \\
\hline & $\mathrm{N}$ & Average & Min & Max & PC1 $(82.4 \%)$ & PC2 $(8.3 \%)$ & PC3 $(4.9 \%)$ \\
\hline Organic content $\left(\mathrm{mg} \mathrm{g}^{-1} \mathrm{dw}\right)^{*}$ & 42 & 3.9 & 28.8 & 145 & 0.352 & -0.186 & -0.019 \\
\hline $\mathrm{C}(\% \mathrm{dw})^{*}$ & 38 & 0.19 & 1.03 & 5.00 & 0.350 & -0.138 & -0.044 \\
\hline $\mathrm{N}(\% \mathrm{dw})^{*}$ & 42 & 0.013 & 0.115 & 0.820 & 0.354 & -0.054 & -0.231 \\
\hline $\mathrm{P}(\% \mathrm{dw})^{*}$ & 41 & 0.009 & 0.030 & 0.141 & 0.349 & 0.011 & -0.022 \\
\hline $\mathrm{H}_{2} \mathrm{~S}\left(\mu \mathrm{mol} \mathrm{l} l^{-1}\right)^{*}$ & 41 & 0.68 & 234 & 4424 & 0.201 & 0.963 & 0.075 \\
\hline Silt-clay $(\% \mathrm{dw}<63 \mu \mathrm{m})^{*}$ & 42 & 0.95 & 15.9 & 73.4 & 0.290 & -0.118 & 0.905 \\
\hline Water content $(\%)^{*}$ & 42 & 15.4 & 29.0 & 72.1 & 0.360 & -0.029 & -0.098 \\
\hline Density $\left(\mathrm{g} \mathrm{ww} \mathrm{cm}^{-3}\right.$ ) & 42 & 1.30 & 1.96 & 2.40 & -0.351 & 0.027 & 0.330 \\
\hline Porosity $\left(\mathrm{ml} \mathrm{cm}^{-3}\right)$ & 42 & 0.36 & 0.54 & 0.98 & 0.358 & -0.028 & -0.041 \\
\hline
\end{tabular}
variables on the PCs. ${ }^{*}$ indicates that the variable was log-transformed before analysis 
the light attenuation coefficient $\left(K_{d}\right)$ relates to Secchi depth $\left(Z_{\mathrm{SD}}\right)$ according to the expression: $K_{d}=1.7 \times$ $Z_{\mathrm{SD}}{ }^{-1}$ (Poole \& Atkins 1929, Højerslev 1978). We then inserted this expression of $K_{d}$ in the formula describing the exponential reduction of light through the water column:

$$
I_{Z}=I_{0} \times \mathrm{e}^{-1.7 \times Z_{\mathrm{SD}}}{ }^{-1} \times Z
$$

where $I_{0}$ represents the sub-surface irradiance, set at $100 \%$, and $I_{z}$ represents light at the depth $Z_{\text {, in our }}$ case equaling the depth limit.

\section{RESULTS}

\section{Depth limits and Secchi depths}

Eelgrass depth limits and Secchi depths varied markedly among sites. Depth limits ranged from 1.5 to $6.4 \mathrm{~m}$ with a mean of $3.5 \mathrm{~m}$, while Secchi depths ranged between 2.5 and $8.2 \mathrm{~m}$ with a mean of $4.8 \mathrm{~m}$. A linear regression of depth limits against Secchi depths was highly significant, and Secchi depths explained $82 \%$ of the variation in depth limits across sites $\left(\mathrm{R}^{2}=0.82, \mathrm{p}<\right.$ 0.0001 , Fig. 2). We found that eelgrass growing at the average depth limit received $28 \%$ of surface irradiance.

\section{Sea bottom characteristics}

Chemical as well as physical characteristics of the sediment also showed marked variation between sites, and sediment variables were highly correlated (Table 2, Fig. 3). Sediments rich in organic matter typically had high concentrations of total-nitrogen, totalphosphorus and hydrogen sulfide. Moreover, organicrich sediments tended to be composed of fine particles, i.e. dominated by silt and clay, and to have high water content, high porosity and low density (Table 2, Fig. 3).

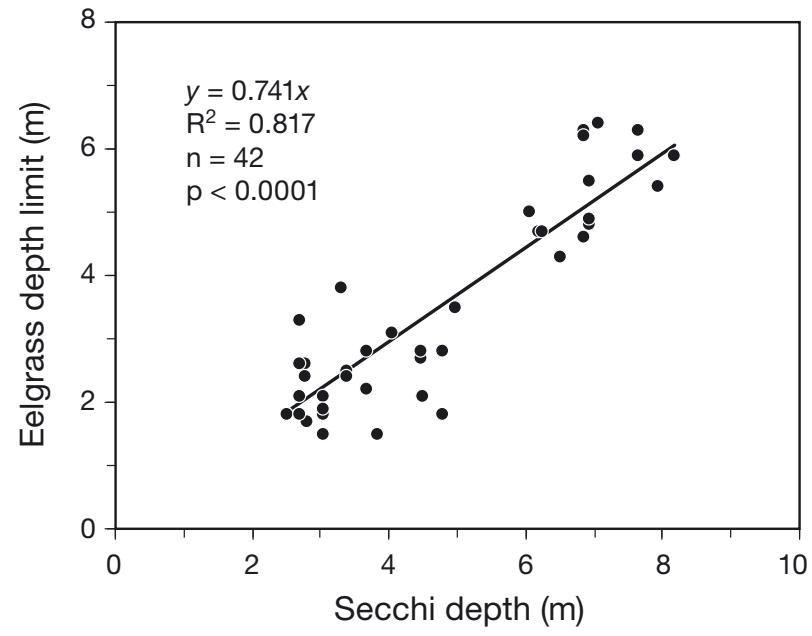

Fig. 2. Zostera marina. Depth limit of eelgrass as a function of Secchi depth in 42 Danish coastal areas. A linear regression line and associated statistics are indicated. The intercept was not significant and therefore set to zero

\section{Effects of sea bottom characteristics on depth limits}

In addition to the variations in depth limits explained by differences in Secchi depths, the remaining variations, i.e. the eelgrass anomalies, were related to the sediment variables and combinations of these, as obtained through PCA, in a combined model (including Secchi depth and the sediment variables, one at a time) analyzed with the GAM and the threshold model. The first principal component (PC1) included all sediment variables but was only influenced slightly by hydrogen sulfide (Table 1). PC2 mainly reflected sulfide concentrations while PC3 mainly reflected siltclay content and density, i.e. physical variables (Table 1). Eelgrass anomalies were significantly related to total-nitrogen concentration of the sediment, silt-clay content, density and PC1, in spite of consider-

Table 2. Zostera marina. Inter-correlations (Pearson's correlation coefficient r) for 9 variables used to characterize the sediment at the depth limit of eelgrass. All values are given as averages from the upper $10 \mathrm{~cm}$ of the sediment, except $\mathrm{H}_{2} \mathrm{~S}$ where values represent the upper $7 \mathrm{~cm}$. ${ }^{*}$ indicates that the variable was log-transformed before analysis

\begin{tabular}{|c|c|c|c|c|c|c|c|c|c|}
\hline & Org $^{*}$ & $\mathrm{C}^{*}$ & $N^{*}$ & $\mathrm{P}^{*}$ & $\mathrm{H}_{2} \mathrm{~S}^{*}$ & $\mathrm{~S}-\mathrm{C}^{*}$ & $\mathrm{WC}^{*}$ & Dens. & Por. \\
\hline Organic content $\left(\mathrm{mg} \mathrm{g}^{-1} \mathrm{dw}\right)^{*}$ & 1.00 & 0.94 & 0.91 & 0.90 & 0.40 & 0.76 & 0.93 & -0.92 & 0.92 \\
\hline $\mathrm{C}(\% \mathrm{dw})^{*}$ & & 1.00 & 0.93 & 0.87 & 0.43 & 0.74 & 0.92 & -0.90 & 0.93 \\
\hline $\mathrm{N}(\% \mathrm{dw})^{*}$ & & & 1.00 & 0.92 & 0.48 & 0.68 & 0.95 & -0.95 & 0.94 \\
\hline$P(\% d w)^{*}$ & & & & 1.00 & 0.52 & 0.74 & 0.92 & -0.92 & 0.90 \\
\hline $\left.\mathrm{H}_{2} \mathrm{~S}(\mu \mathrm{mol} \mathrm{l})^{-1}\right)^{*}$ & & & & & 1.00 & 0.38 & 0.51 & -0.49 & 0.51 \\
\hline Silt-clay $(\% \mathrm{dw}<63 \mu \mathrm{m})^{*}$ & & & & & & 1.00 & 0.74 & -0.64 & 0.75 \\
\hline Water content $(\%)^{*}$ & & & & & & & 1.00 & -0.95 & 0.99 \\
\hline Density ( $\mathrm{g}$ ww $\mathrm{cm}^{-3}$ ) & & & & & & & & 1.00 & -0.92 \\
\hline Porosity $\left(\mathrm{ml} \mathrm{cm}^{-3}\right)$ & & & & & & & & & 1.00 \\
\hline
\end{tabular}



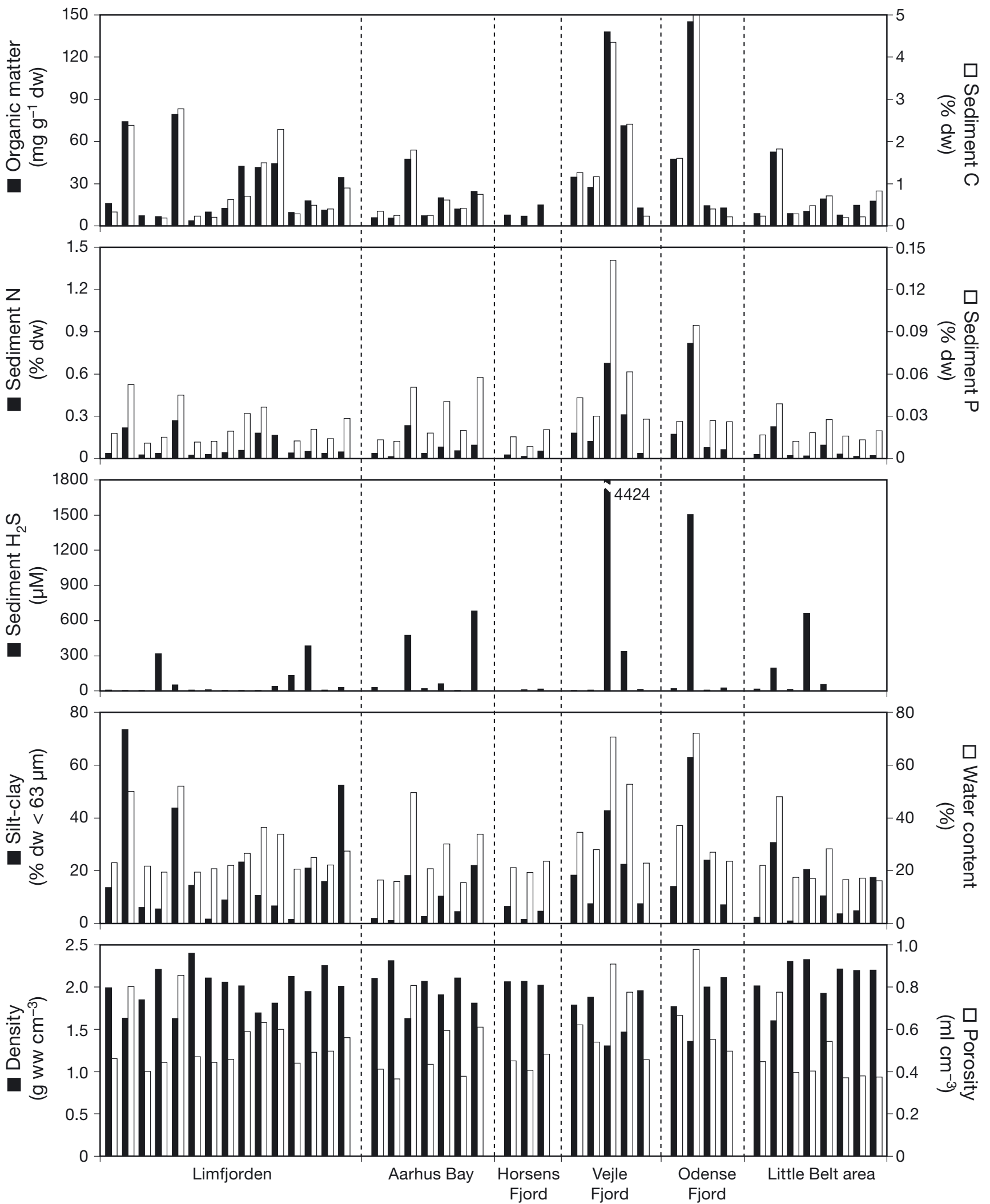

Fig. 3. Zostera marina. Physical and chemical characteristics of the sea bottom at the depth limit of eelgrass in Danish coastal waters. All values are given as averages from the upper $10 \mathrm{~cm}$ of the sediment, except $\mathrm{H}_{2} \mathrm{~S}$ concentrations, which represent the upper $7 \mathrm{~cm}$ of sediment 
Table 3. Zostera marina. Depth limits modeled in relation to Secchi depths $\left(Z_{\mathrm{SD}}\right)$ and sediment variables, including the first 3 principal components of these (PC1 to PC3, see Table 1), using a non-parametric Generalized Additive Model (GAM) and a parametric threshold model. Both models include a linear regression coefficient for $Z_{\mathrm{SD}}\left(a_{\mathrm{GAM}}\right.$ and $a_{\mathrm{THRES}}$, respectively). The GAM model was chosen by generalized cross validation, resulting in variable degrees of freedom (df) for the smoother [S(X)]. Probabilities for the 2 models (p) denote the significance of the functional expression for the sediment variable. Estimated thresholds for sediment variables are listed with an interval [mean $-\mathrm{SE}_{;}$mean $+\mathrm{SE}$ ] displaying the confidence of the estimate, but are not given for the cases where the threshold was determined by only 2 points and therefore not well determined (indicated by*)

\begin{tabular}{|c|c|c|c|c|c|c|c|c|c|}
\hline \multirow[t]{2}{*}{ Explanatory variable $(X)$} & \multirow[t]{2}{*}{ No. of obs. } & \multicolumn{4}{|c|}{$\longrightarrow$ GAM model } & \multirow[b]{2}{*}{$a_{\text {THRES }}$} & \multirow{2}{*}{$\begin{array}{l}\text { Threshold model } \\
\text { Threshold }\end{array}$} & \multirow[b]{2}{*}{$\mathrm{p}$} & \multirow[b]{2}{*}{$\mathrm{R}^{2}$} \\
\hline & & $a_{\mathrm{GAM}}$ & $\mathrm{df}$ & $\mathrm{p}$ & $\mathrm{R}^{2}$ & & & & \\
\hline Organic content (log) & 42 & 0.774 & 1.29 & 0.0567 & 0.838 & 0.751 & $134^{*} \mathrm{mg} \mathrm{g}^{-1} \mathrm{dw}$ & 0.0147 & 0.850 \\
\hline $\mathrm{C}(\log )$ & 38 & 0.769 & 1.28 & 0.1150 & 0.847 & 0.758 & $3.99 * \% \mathrm{dw}$ & 0.0125 & 0.856 \\
\hline $\mathrm{N}(\log )$ & 42 & 0.784 & 1.96 & 0.0225 & 0.849 & 0.751 & $0.606 * \% d w$ & 0.0146 & 0.850 \\
\hline P (log) & 41 & 0.805 & 3.26 & 0.0605 & 0.868 & 0.748 & $0.052[0.034 ; 0.081] \% \mathrm{dw}$ & 0.0707 & 0.853 \\
\hline $\mathrm{H}_{2} \mathrm{~S}(\log )$ & 41 & 0.802 & 1.52 & 0.0548 & 0.840 & 0.770 & $13.4[1.5 ; 119.0] \mu \mathrm{mol} \mathrm{l} \mathrm{l}^{-1}$ & 0.1188 & 0.833 \\
\hline Silt-clay (log) & 42 & 0.795 & 3.05 & 0.0384 & 0.853 & 0.763 & $13.3[7.2 ; 24.5] \% \mathrm{dw}<63 \mu \mathrm{m}$ & 0.0822 & 0.838 \\
\hline Water content (log) & 42 & 0.788 & 1.58 & 0.0731 & 0.838 & 0.751 & $69.8 * \%$ & 0.0146 & 0.850 \\
\hline Density & 42 & 0.789 & 2.15 & 0.0240 & 0.851 & 0.753 & $1.63[1.48 ; 1.78] \mathrm{g} \mathrm{ww} \mathrm{cm}^{-3}$ & 0.0294 & 0.845 \\
\hline Porosity & 42 & 0.782 & 1.30 & 0.0524 & 0.838 & 0.753 & $0.831[0.56 ; 1.11] \mathrm{ml} \mathrm{cm}^{-3}$ & 0.0130 & 0.851 \\
\hline PC1 & 36 & 0.800 & 1.39 & 0.0474 & 0.872 & 0.756 & $3.52[2.22 ; 4.82]$ & 0.0109 & 0.867 \\
\hline $\mathrm{PC} 2$ & 36 & 0.850 & 2.86 & 0.0890 & 0.877 & 0.774 & $-0.144[-1.19 ; 0.91]$ & 0.2041 & 0.847 \\
\hline PC3 & 36 & 0.822 & 1.39 & 0.4948 & 0.856 & 0.774 & $0.475[-1.43 ; 2.38]$ & 0.5648 & 0.838 \\
\hline
\end{tabular}

able scatter in the relationships (GAM model, $\mathrm{p}<0.05$; Table 3, Fig. 4: black lines). Negative effects on depth limits only appeared at the highest concentrations measured (Fig. 4). Sediment contents of phosphorus, hydrogen sulfide and organic matter as well as water content and porosity of the sediment showed the same tendency but relationships were not significant. Neither PC2 nor PC3 were significantly related to the eelgrass anomalies (GAM model, p > 0.05; Table 3, Fig. 4: black lines).

Since the GAM model indicated that negative effects on depth limits only occurred at the highest levels of sediment variables measured, we attempted to identify the threshold levels triggering the negative effects. Threshold models were significant when applied to sediment organic content, carbon content, nitrogen content, water content, density, porosity and PC1 (Threshold model, p < 0.05; Table 3, Fig. 4: gray solid lines), and approached significance for phosphorus content, hydrogen sulfide content and silt-clay. The threshold levels were estimated at $134 \mathrm{mg}$ organic matter $\mathrm{g}^{-1}$ dry weight [dw], $4.0 \% \mathrm{C}, 0.61 \% \mathrm{~N}, 0.052 \%$ $\mathrm{P}, 13 \mu \mathrm{mol} \mathrm{l^{-1 }} \mathrm{H}_{2} \mathrm{~S}, 13 \%$ silt-clay content, $70 \%$ water

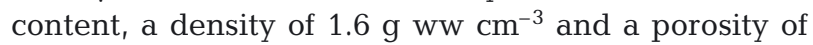
$0.83 \mathrm{ml} \mathrm{cm}^{-3}$ (Table 3). In the case of nitrogen content, carbon content, organic content and water content, the threshold levels were assessed on the basis of only the 2 extreme sediment values and therefore not well determined (Table 3, marked by asterisks). For the remaining sediment variables, the threshold level was better determined though still associated with considerable inaccuracy (Table 3 ). A more robust determina- tion of threshold levels would have demanded data representing more extreme sediment conditions. However, sediments with a composition completely unsuitable for eelgrass growth could not be included in the model since they did not have associated data on eelgrass depth limits, and it would not be possible to identify the depth where sediment should be sampled.

Including the overall range of sediment variables in addition to the Secchi depth in the models resulted in steeper slopes for the proportionate relationship of depth limits to Secchi depths ranging from 0.77 to 0.85 for the GAM model and from 0.75 to 0.77 for the threshold model (Table 3) as opposed to 0.74 in the model with Secchi depth as the only explanatory variable (Fig. 2). These results, in turn, decreased the estimate of the compensating irradiance level from $28 \%$ of surface irradiance when sediment characteristics were not included, to ranges of 24 to $27 \%$ and 27 to $28 \%$ when including the overall range of sediment variables in the GAM and thresholds models, respectively.

\section{DISCUSSION}

\section{Eutrophic conditions have a double negative effect on eelgrass depth limits}

The study supported our hypothesis that even though light attenuation is by far the main predictor of eelgrass depth limits, sediment characteristics also play a regulating role. At a given light attenuation, depth limits were moderately shallower when the sea bottom was 


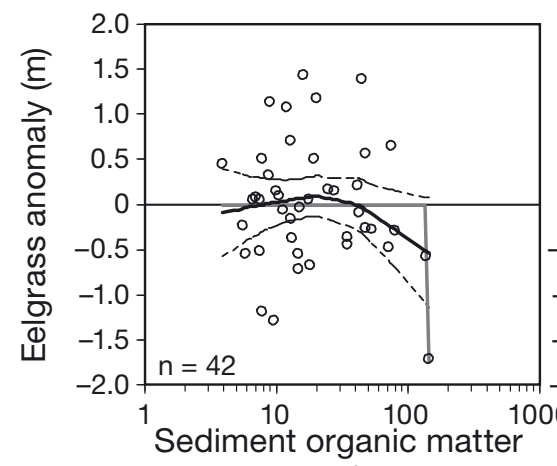

( $\mathrm{mg} \mathrm{g}^{-1} \mathrm{dw}$ )

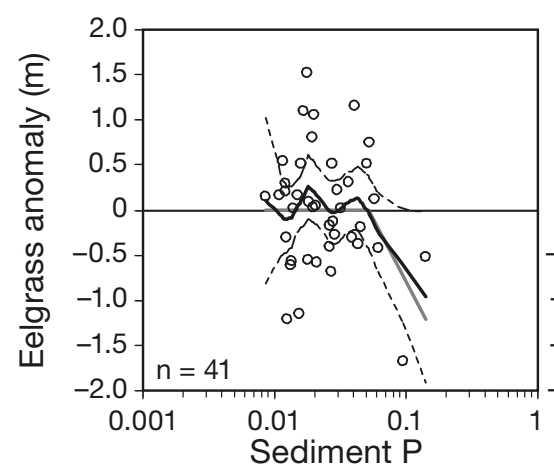

(\% dw)

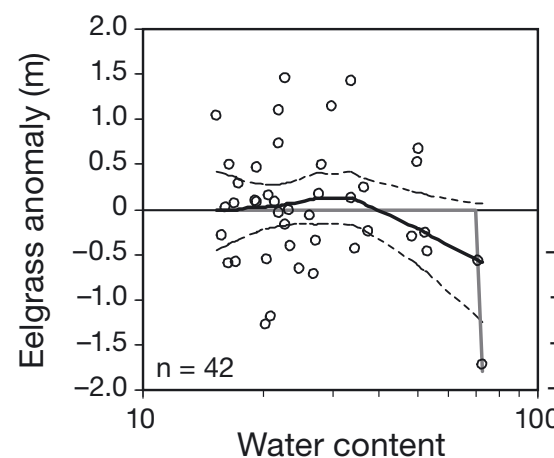

(\%)
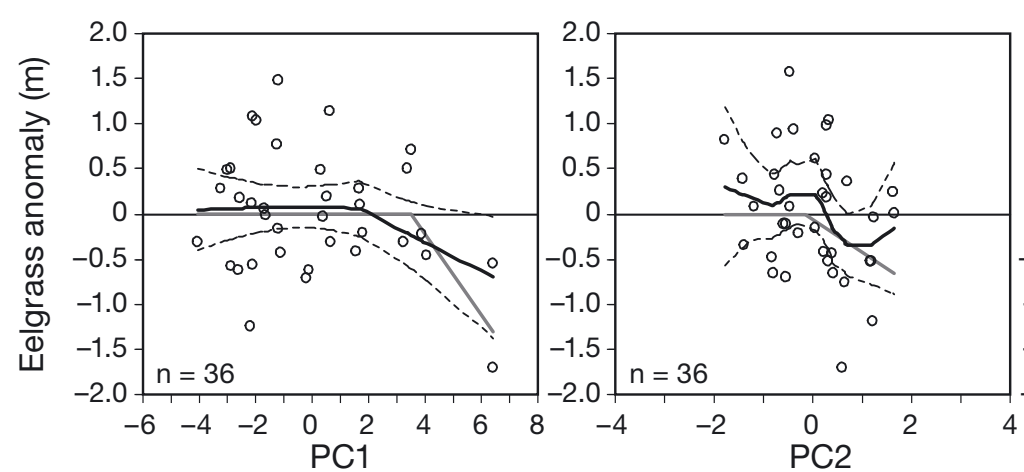

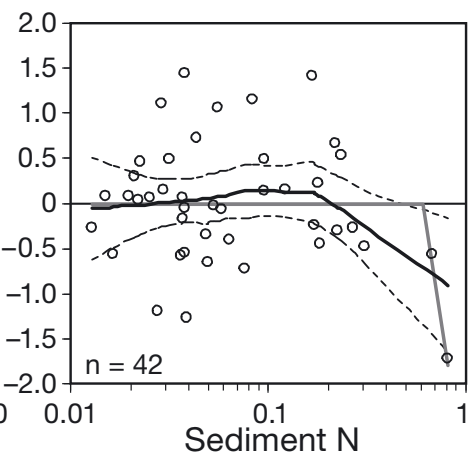

(\% dw)

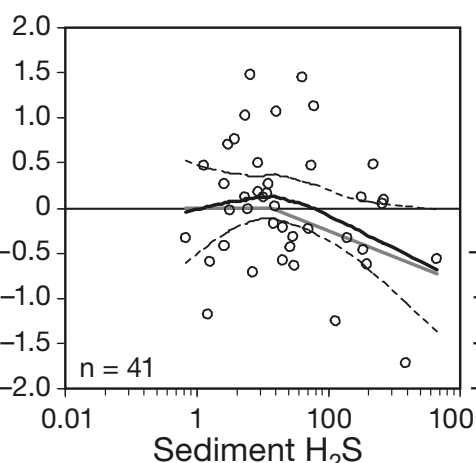

$(\mu \mathrm{M})$

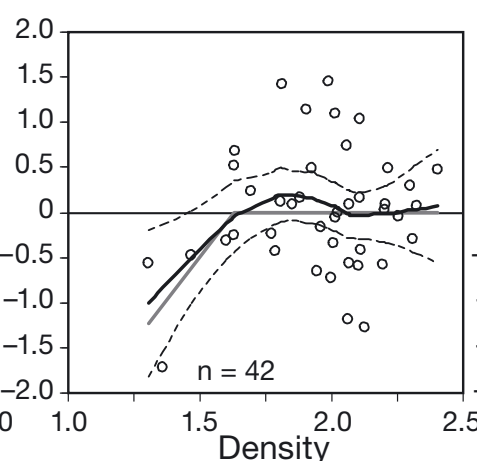

(g ww cm-3)

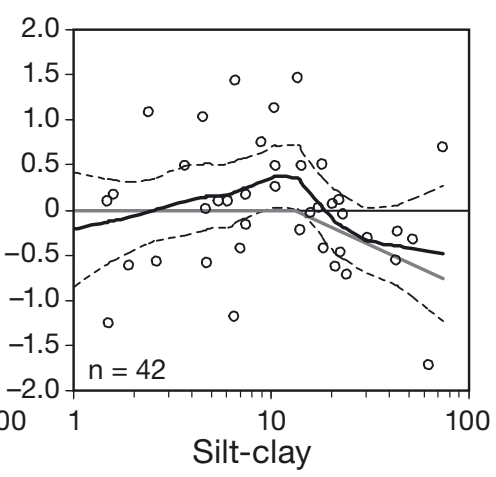

(\% dw <63 $\mu \mathrm{m}$ )

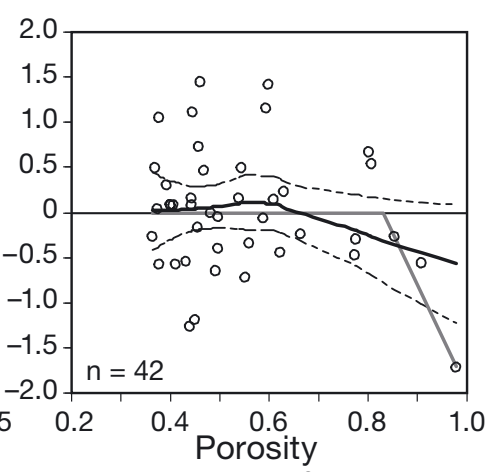

$\left(\mathrm{ml} \mathrm{cm}^{-3}\right)$

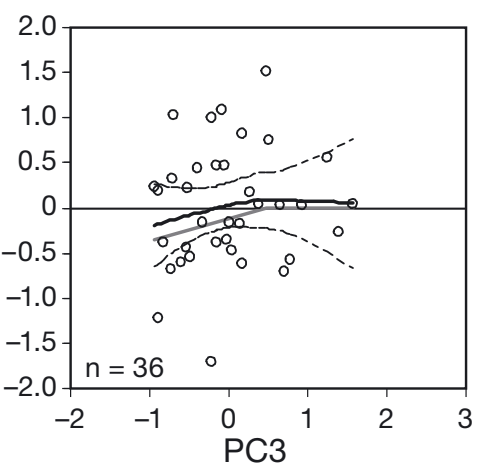

Fig. 4. Zostera marina. 'Eelgrass anomalies' representing deviations (residuals) from the relationship between eelgrass depth limits and Secchi depths, modeled in relation to various sediment variables. Open circles represent data from individual sites. The models include non-parametric relationships (black lines, $S(X)$ with $95 \%$ confidence bands) and parametric threshold relationships (gray lines, broken in the cases where the threshold is determined by 2 influential observations only). Sediment variables represent physical and chemical sediment characteristics as well as the first 3 principal components (PC1 to PC3) of a Principal Component Analysis (PCA). Statistics of the PCA analysis are shown in Table 1; those of GAM models and threshold models are shown in Table 3 
rich in organic material, had high concentrations of nutrients and hydrogen sulfide and a physical structure characterized by fine particles, high porosity, high water content and low density. Sediment variables were highly correlated and did therefore not allow identification of a single determinant but clearly showed that the above-mentioned physico-chemical conditions caused shallower depth limits. These sediment characteristics are typically associated with eutrophic conditions which can be anthropogenic or naturally occurring, and are also associated with hydrodynamic conditions promoting sedimentation. Discharges of nutrients from land thus stimulate the production of phytoplankton and opportunistic macroalgae that subsequently accumulate on the sea bottom of physically protected areas and give rise to high contents of organic matter and nutrients as well as a soft sediment structure. Dense and healthy seagrass meadows may enhance sedimentation and create organic-rich sediment, but this effect was probably minor in the present study, since sediment was sampled near the depth limit of the plants where only sparse shoots were present. Relatively organicrich and finely grained sediments also occur naturally in deeper and protected areas where sedimentation is enhanced.

Experimental enrichment of seagrass sediments with organic matter and nutrients has been found to increase the pools of hydrogen sulfide in the sediment, create more reduced sediments and cause a lower biomass and a higher mortality of seagrasses (Pérez et al. 2007). Our study showed that similar relationships between high concentrations of organic matter, high nutrient and sulfide concentrations and negative seagrass response exist on a large spatial scale in situ. Sulfide is a likely candidate to trigger the negative response as it has toxic effects (Goodman et al. 1995, Holmer \& Bondgaard 2001) and can enter seagrass tissue when low oxygen concentration in the water column or low rates of net photosynthesis create low oxygen concentrations within the tissue and thus a reduced ability to oxidize sulfide (Pedersen et al. 2004, Borum et al. 2005). Sediments characteristic of eutrophic conditions may further hamper seagrasses by increasing the risk of anoxic events, and seagrasses at the depth limit may be particularly susceptible to this kind of stress as they have low growth potential. Our study does not exclude the possibility that periodic oxygen depletion of the bottom water, co-varying with sediment characteristics, could cause reductions in eelgrass depth limits.

The results further suggested that also the physical attributes of organic-rich sediments, in terms of a soft, fine and watery structure, may affect eelgrass negatively. This effect is in line with the findings of Wicks et al. (2009) that soft sediments provide a low anchoring capacity for eelgrass shoots and thus an increased risk of physical removal. Fine sediments also affect the light climate since they are prone to resuspension. This effect should be largely accounted for in our model, which describes light attenuation (expressed as Secchi depth) as the primary determinant of eelgrass depth limits, but resuspension of fine sediments near the sea bottom could escape our measurements and thereby cause an underestimation of light attenuation.

The identified effect of sediment quality on eelgrass depth limits implies that eutrophication has a double negative effect on eelgrass depth limits, by increasing light attenuation and reducing sediment quality. This finding may help explain why depth limits at a given Secchi depth can vary largely between areas (e.g. Nielsen et al. 2002, Duarte et al. 2007). Our estimates of threshold levels of sediment variables can help managers to evaluate whether sediment quality might be a problem in a given area. Danish coastal waters experienced marked eutrophication during the 20th century with nitrogen loads peaking in 1980 at about 4 to 5 times the level in 1900 (Conley et al. 2007). Nutrient loads are still high, but reduction measures undertaken since the late 1980s have reduced the external loads to about 2 to 3 times the 1900 level (Conley et al. 2007, Hjorth \& Josefson 2010), and the internal sediment based load originating from past eutrophication events has probably also declined. The high betweensite variability in sediment variables found in our study may partly reflect variable distance to present and past sources of nutrient load in combination with differences in sedimentation and resuspension among sites.

A warmer climate is likely to increase the negative effects of eutrophication on eelgrass by pushing the carbon and oxygen balance of the plants in a negative direction. High temperatures stimulate single plant and community respiration to a greater extent than photosynthesis, thereby creating lower internal oxygen concentrations (Greve et al. 2003) and higher light demands of eelgrass (Olesen \& Sand-Jensen 1993, Short \& Neckles 1999, Ralph et al. 2007, Moore \& Jarvis 2008). Higher temperatures also reduce the solubility and thereby the content of oxygen in the water column, and warming is likely to increase the frequency of anoxic events (Conley et al. 2007), while at the same time decreasing the tolerance of eelgrass to anoxia (Pulido \& Borum 2010).

\section{The sea bottom exerts a threshold effect on eelgrass depth limits}

The effect of sediment characteristics on eelgrass was nonlinear, influencing depth limits only when measured variables exceeded threshold levels. Seagrass medows are well adapted to organic-rich sediments 
since they produce and accumulate organic matter (Hemminga 1998), and this may explain why we only see negative effects of increasing organic content and associated sediment variables when these exceed threshold levels. Our analyses provided a preliminary estimate of these threshold levels, though with considerable associated error (Table 3 ). The estimated threshold level of sediment organic matter of around $134 \mathrm{mg}$ $\mathrm{g}^{-1} \mathrm{dw}$ or $13 \%$ of dry weight, was close to the maximum of $16 \%$ of dry weight for healthy eelgrass beds reported in a literature compilation (Koch 2001). We have found no threshold values for $\mathrm{N}$ content of the sediment in the literature to compare with our result ( $0.61 \% \mathrm{~N}$ of dry weight). However, this level seems a reasonable threshold level since it is in the high end of $\mathrm{N}$ contents recorded in shallow bays of other studies, e.g. 0.13 to $0.67 \% \mathrm{~N}$ in shallow ( 0 to $5 \mathrm{~m}$ ) Danish fjords (T. Dalsgaard unpubl. data); $0.2 \pm 0.06 \% \mathrm{~N}$ in fine, organic-rich sediments with Zostera noltii and $0.08 \pm$ $0.06 \% \mathrm{~N}$ in coarser sediments colonized by macroalgae (Figueiredo da Silva et al. 2009); 0.2 to $0.34 \% \mathrm{~N}$ in sediments below plant canopies as compared to 0.18 to $0.19 \% \mathrm{~N}$ in bare sediments (Castro et al. 2009); and 0.05 to $0.1 \% \mathrm{~N}$ in surface sediments of vegetated salt marshes (Wang et al. 2010).

Our study indicated negative effects of sulfide in the sediment at a threshold level as low as $13 \mu \mathrm{mol} \mathrm{l}^{-1}$, which is significantly lower than previously reported in the literature. For comparison, Goodman et al. (1995) found that hydrogen sulfide levels of around $400 \mu \mathrm{mol}$ $\mathrm{l}^{-1}$ in the sediment reduced the photosynthetic rates of eelgrass. Terrados et al. (1999) observed reduced leaf growth of eelgrass at sediment hydrogen sulfide levels of around $75 \mu \mathrm{mol} \mathrm{l} \mathrm{l}^{-1}$, while Holmer \& Bondgaard (2001) found that the photosynthetic activity of eelgrass stopped after exposure to hydrogen sulfide concentrations in the water column of 100 to $1000 \mu \mathrm{mol} \mathrm{l}^{-1}$. The lower thresholds of our study may be due to the fact that we studied light stressed eelgrass growing at the edge of its distribution. It was therefore likely to be particularly susceptible to additional stress arising from sediments conditions, as well as to combinations of sediment stressors. In contrast, the experimental studies referred to above focused on sulfide as the only stress factor. Moreover, our estimates of threshold levels were associated with some uncertainty and should be seen as no more than an indication of the sulfide levels above which detrimental effects on eelgrass may be expected.

Regarding the silt-clay content, our study showed a threshold level of $13 \%$, while Koch (2001) observed healthy eelgrass populations at silt-clay contents as high as $56 \%$ (range 2 to $56 \%$ ). The tolerance of eelgrass to physical conditions such as soft, finely textured sediments and, thus, poor anchoring conditions, is likely to vary between areas, due to differences in exposure to currents and waves (Wicks et al. 2009).

The comparisons between threshold levels of sediment variables, in our and other studies, suggest that thresholds leading to eelgrass decline vary among habitats due to interaction with other stress factors such as shading and physical exposure and possibly interaction among sediment variables. It is probable that unfavorable chemical sediment conditions are more of a problem for deep, shaded eelgrass populations than for populations living in shallow light saturated habitats; while soft sediments with low anchorage support are more problematic for shallow eelgrass populations in exposed environments. A combination of unfavorable physico-chemical sediment conditions across the entire depth range may, therefore, further accentuate the pattern of eelgrass being constrained to intermediate water depths where moderate light levels are combined with moderate levels of physical exposure (Krause-Jensen et al. 2003). If depth limits rose to exclude eelgrass from all but very shallow waters, due to extremely high turbidity, plants growing within the depth limit would be highly vulnerable to higher drag forces in the shallow waters.

\section{High light demand of eelgrass in turbid, eutrophic areas}

Eelgrass growing at the depth limit had relatively high apparent light demands equaling $28 \%$ of surface irradiance as calculated from the depth limits modeled in relation to Secchi depths (Fig. 2) and using the average Secchi depth of the generally turbid, eutrophic waters included in our study. For comparison, we also calculated the light demands based on a combined model incorporating sediment variables (Table 3), thereby to some extent subtracting the effect of sediments on light demands. These models predicted slightly lower light demands at the depth limit ( $24 \%$ to $28 \%$ of surface irradiance), suggesting that unfavorable sediment conditions could explain at least part of the high light demand observed in these Danish eelgrass populations and the associated shallow depth limits. Previous studies have reported increasing light requirements of seagrasses along a gradient from clear, oligotrophic waters towards turbid, eutrophic waters (Duarte et al. 2007), and our study suggests that unfavorable sediment conditions is one of several explanations for this pattern. Experimentally determined light compensation points for growth of Danish eelgrass populations have been found to equal $11 \%$ of surface irradiance in the laboratory (Olesen \& SandJensen 1993), and are thus considerably lower than those determined in the field. This discrepancy proba- 
bly reflects that depth limits in the field represent the long-term compensation depth for survival, i.e. the depth where plants can persist year round and cope with stress factors such as those connected with unfavorable sediments, anoxic events and additional shading due to epiphytes or algal mats. In contrast, experimental studies generally represent shorter time scales and a less stressful environment. However, light measurements from the central part of the basins, as used in this study, may slightly overestimate light availability in eelgrass habitats closer to the shore, where resuspension of bottom material is likely to be more pronounced, leading to higher particle concentrations in the water column. This will be the case if denser eelgrass of the shallow zone does not fully counteract this effect by enhancing sedimentation and stabilizing the sediment and if clearing of the water column by bivalve filtration is similar among the deeper and shallower sites.

In conclusion, our study indicates that sediment conditions play a role in controlling the depth limit of eelgrass and that light attenuation is, therefore, not the only player. Even though seagrasses are adapted to surviving in organic-rich sediments, their depth colonization is limited when the content of organic matter and associated variables in the sediment exceed threshold levels. Negative effects of eutrophication in terms of light attenuation, unsuitable sediment quality, and increased risk of water column anoxia, highlight the need for further reductions in nutrient load in order to promote the restoration of seagrass beds. The depth limit of eelgrass may not respond immediately to reduced external nutrient loads and the response is likely to vary between areas. Resuspended materials, which are only indirectly related to nutrient loads may contribute markedly to light attenuation in some areas (e.g. Olesen 1996, Carr et al. 2010). Physically protected areas will maintain relatively high sedimentation rates, and the sediments represent a 'memory' of past eutrophication, which may prevail for years after reductions of external loads.

Acknowledgements. We thank our colleagues from the Danish counties/regions for collecting data on eelgrass and sediments and providing local information on the sampling sites: B. Sømod, F. Andersen, J. S. Laursen, M. Laursen, N. Holmboe, S. Schwærter, S. Bråten and T. Jørgensen. K. Linding Gerlich, E. Frandsen, M. V. Skjærbæk and T. Quottrup, all from the National Environmental Research Institute, University of Aarhus, are thanked for performing the laboratory analyses. The project received financial support from the Danish National Monitoring and Assessment Programme for the Aquatic and Terrestrial Environment (NOVANA), the EU projects 'THRESHOLDS' contract \#003933-2 and 'WISER' contract \#226273 as well as the Danish Agency for Science, Technology and Innovation (grant \#09-063190/DSF and research stay for D.K.J.).

\section{LITERATURE CITED}

Borum J (1985) Development of epiphytic communities on eelgrass (Zostera marina) along a nutrient gradient in a Danish estuary. Mar Biol 87:211-218

Borum J, Pedersen O, Greve TM, Frankovich TA, Zieman JC, Fourqurean JW, Madden C (2005) The potential role of plant oxygen and sulfide dynamics for die-off events of the tropical seagrass, Thalassia testudinum, in Florida Bay. J Ecol 93:148-158

> Burkholder JM, Tomasko DA, Touchette BW (2007) Seagrasses and eutrophication. J Exp Mar Biol Ecol 350:46-72

Carr J, D'Odorico P, McGlathery K, Wiberg P (2010) Stability and bistability of seagrass ecosystems in shallow coastal lagoons: role of feedbacks with sediment resuspension and light attenuation. J Geophys Res 115:G03011 doi:10. 1029/2009JG001103

Castro P, Valiela I, Freitas H (2009) Sediment pool and plant content as indicators of nitrogen regimes in Portuguese estuaries. J Exp Mar Biol Ecol 380:1-10

Cline JD (1969) Spectrophotometric determination of hydrogen sulfide in natural waters. Limnol Oceanogr 14: $454-458$

Conley D, Carstensen J, Ærtebjerg G, Christensen PB, Dalsgaard T, Hansen JLS, Josefson A (2007) Long-term changes and impacts of hypoxia in Danish coastal waters. Ecol Appl 17:S165-S184

Dennison WC (1987) Effects of light on seagrass photosynthesis, growth and depth distribution. Aquat Bot 27:15-26

> Dierssen HM, Zimmerman RC, Leathers RA, Downes TV, Davis CO (2003) Ocean color remote sensing of seagrass and bathymetry in the Bahamas Banks by high-resolution airborne imagery. Limnol Oceanogr 48:444-455

Drake LA, Dobbs FC, Zimmerman RC (2003) Effects of epiphyte load on optical properties and photosynthetic potential of the seagrasses Thalassia testudinum Banks ex Konig and Zostera marina L. Limnol Oceanogr 48:456-463

> Duarte CM (1991) Seagrass depth limits. Aquat Bot 40: 363-377

Duarte CM, Holmer M, Marbà N (2005) Plant-microbe interactions in seagrass meadows. In: Kristensen E, Haese RR, Kostka J (eds) Macro-and microorganisms in marine sediments. Coast Estuar Stud 60, Am Geophys Union, Washington, DC, p 31-60

Duarte CM, Marbà N, Krause-Jensen D, Sánchez-Camacho M (2007) Testing the predictive power of seagrass depth limit models. Estuaries Coasts 30:652-656

> Figueiredo da Silva J, Duck RW, Catarino JB (2009) Nutrient retention in the sediments and the submerged aquatic vegetation of the coastal lagoon of the Ria da Aveiro, Portugal. J Sea Res 62:276-285

> Goodman JL, Moore KA, Dennison WC (1995) Photosynthetic responses of eelgrass (Zostera marina L.) to light and sediment sulfide in a shallow barrier island lagoon. Aquat Bot 50:37-47

Green EP, Short FT (2003) World atlas of seagrasses. University of California Press, Berkeley, CA

Greve TM, Krause-Jensen D (2005) Predictive modelling of eelgrass (Zostera marina L.) depth limits. Mar Biol 146: 849-858

Greve TM, Borum J, Pedersen O (2003) Meristematic oxygen variability in eelgrass (Zostera marina). Limnol Oceanogr 48:210-216

Hastie TJ, Tibshirani RJ (1990) Generalized additive models. Chapman \& Hall, New York, NY

> Hemminga MA (1998) The root/rhizome system of seagrasses: an asset and a burden. J Sea Res 39:183-196 
Hemminga MA, Duarte CM (2000) Seagrass ecology. Cambridge University Press, Cambridge

Hjorth M, Josefson AB (eds) (2010) Marine områder 2008. NOVANA. Tilstand og udvikling i miljø- og naturkvaliteten. Scientific report 760, National Environmental Research Institute, Aarhus University (in Danish with English summary). www.dmu.dk/Pub/FR760.pdf

Højerslev NK (1978) Daylight measurements appropriate for photosynthetic studies in natural sea water. J Cons Int Explor Mer 38:131-145

Holmer M, Bondgaard EJ (2001) Photosynthetic and growth response of eelgrass to low oxygen and high sulfide concentrations during hypoxic events. Aquat Bot 70:29-38

Kemp WM, Batleson R, Bergstrom P, Carter V, Gallegos CL and others (2004) Habitat requirements for submerged aquatic vegetation in Chesapeake Bay: water quality, light regime, and physical-chemical factors. Estuaries 27: 363-377

Koch EM (2001) Beyond light: physical, geological, and geochemical parameters as possible submersed aquatic vegetation habitat requirements. Estuaries 24:1-17

Koroleff F (1983) Determination of phosphorus. In: Grasshoff $\mathrm{K}$, Erhard M, Kremling $\mathrm{K}$ (eds) Methods of seawater analysis, 2nd edn. Verlag Chemie, Weinheim

Krause-Jensen D, Pedersen MF, Jensen C (2003) Regulation of eelgrass (Zostera marina) cover along depth gradients in Danish coastal waters. Estuaries 26:866-877

Mascaró O, Valdemarsen T, Holmer M, Perez M, Romero J (2009) Experimental manipulation of sediment organic content and water column aeration reduces Zostera marina (eelgrass) growth and survival. J Exp Mar Biol Ecol 373:26-34

Moore KA, Jarvis JC (2008) Environmental factors affecting recent summertime eelgrass diebacks in the Lower Chesapeake Bay: implications for long-term persistence. J Coast Res 55:135-147

Nielsen SL, Sand-Jensen K, Borum J, Geertz-Hansen O (2002) Depth colonization of eelgrass (Zostera marina) and macroalgae as determined by water transparency in Danish coastal waters. Estuaries 25:1025-1032

Olesen B (1996) Regulation of light attenuation and eelgrass Zostera marina depth distribution in a Danish embayment. Mar Ecol Prog Ser 134:187-194

Olesen B, Sand-Jensen K (1993) Seasonal acclimatization of eelgrass Zostera marina growth to light. Mar Ecol Prog Ser 94:91-99

Orth RJ, Carruthers TJB, Dennison WC, Duarte CM and others (2006) A global crisis for seagrass ecosystems. Bioscience 56:987-996

Editorial responsibility: Hans Heinrich Janssen, Oldendorf/Luhe, Germany
Pedersen O, Binzer T, Borum J (2004) Sulfide intrusion in eelgrass (Zostera marina L.). Plant Cell Environ 27:595-602

Pérez M, Invers O, Ruiz JM, Frederiksen MS, Holmer M (2007) Physiological responses of the seagrass Posidonia oceanica to elevated organic matter content in sediments: an experimental assessment. J Exp Mar Biol Ecol 344: $149-160$

Plus M, Deslous-Paoli JM, Dagault F (2003) Seagrass (Zostera marina L.) bed recolonisation after anoxia-induced full mortality. Aquat Bot 77:121-134

Poole HH, Atkins WRG (1929) Photo-electric measurements of submarine illumination throughout the year. J Mar Biol Assoc UK 16:297-324

Pulido C, Borum J (2010) Eelgrass (Zostera marina) tolerance to anoxia. J Exp Mar Biol Ecol 385:8-13

> Ralph PJ, Durako MJ, Enriquez S, Collier CJ, Doblin MA (2007) Impact of light limitation on seagrasses. J Exp Mar Biol Ecol 350:176-193

Reinke J (1889) Algenflora der westlichen Ostsee deutschen Anteils. Eine systematisch-pflanzengeographische Studie. In: Karsten G, Hensen V, Reinke J, Brandt K (1893) Sechster Bericht der Kommission zur wissenschaftlichen Untersuchung der deutschen Meere, in Kiel für die Jahre 1887 bis 1891. Paul Parey, Berlin, Heft I, p 1-101

Short FT, Neckles HA (1999) The effects of global climate change on seagrasses. Aquat Bot 63:169-196

> Short FT, Wyllie-Echeverria S (1996) Natural and humaninduced disturbances of seagrass. Environ Conserv 23: $17-27$

- Steward JS, Virnstein RW, Morris LJ, Lowe EF (2005) Setting seagrass depth, coverage, and light targets for the Indian River Lagoon system, Florida. Estuaries 28:923-935

Terrados J, Duarte CM, Kamp-Nielsen L, Agawin NSR and others (1999) Are seagrass growth and survival constrained by the reducing conditions of the sediment? Aquat Bot 65:175-197

Wang JQ, Zhang XD, Jiang LF, Bertness MD and others (2010) Bioturbation of burrowing crabs promotes sediment turnover and carbon and nitrogen movements in an estuarine salt marsh. Ecosystems 13:586-599

> Waycott M, Duarte CM, Carrouthers TJB, Orth RJ and others (2009) Accelerating loss of seagrasses across the globe threatens coastal ecosystems. Proc Natl Acad Sci USA 106: $12377-12381$

- Wicks CE, Koch EW, O'Neil JM, Elliston K (2009) Effects of sediment organic content and hydrodynamic conditions on the growth and distribution of Zostera marina. Mar Ecol Prog Ser 378:71-80

Submitted: August 3, 2010; Accepted: January 7, 2011 Proofs received from author(s): March 7, 2011 